\title{
A Celebration of Life! \\ An African American Ethnic Academy \& BioPharmaceutical Technology Center Institute Science Outreach Partnership
}

\author{
Barbara Bielec \\ BioPharmaceutical Technology Center Institute
}

\begin{abstract}
The primary goal of "A Celebration of Life" is to support the continued development of African American and other students' interest in science, and to assist in providing them with the tools for success in school. A long-term goal is to increase the number of minority students who successfully complete high school science courses and who choose to pursue STEM careers. In partnership with the African American Ethnic Academy, Inc. (AAEA), a Madison non-profit organization, the BioPharmaceutical Technology Center Institute (BTC Institute) offered "A Celebration of Life XVI: Healthy Bodies on Earth and in Space!" during summer 2011. Two week sessions for elementary and middle school students were held weekday mornings at the BioPharmaceutical Technology Center, in Madison, Wisconsin. These programs represent a 16year collaboration between AAEA and the BTC Institute that prioritizes offering a rich range of hands-on science activities for students.
\end{abstract}

\section{Introduction}

The primary goal of "A Celebration of Life" is to support the continued development of African American and other students' interest in science, and to help provide them with the tools for success in school. A long-term goal continues to be increasing the number of minority students who successfully complete high school science courses, and who may eventually choose to pursue science, technology, engineering and math (STEM) careers. Extensive efforts are made to ensure participation of students from economically challenged families through the provision of scholarships and transportation.

\section{Program Details}

The program theme for 2011 was Healthy Bodies on Earth and in Space! For both sessions, content was selected to emphasize how maintaining a healthy body is related to life on earth and to space exploration. Program activities reflect the Wisconsin Model Academic Standards for Science, which follow the form and content of the National Science Education Standards. Many of the educational activities were from the NASA Summer of Innovation project (http://www.nasa.gov/offices/education/programs/national/summer/education_resources/lifescien ce_grades4-6/index.html, 2011).

The BTC Institute is pleased to acknowledge the Wisconsin Space Grant Consortium Special Initiatives Program for their financial support. 
Over $90 \%$ of the student participants were African American. Many received scholarships and transportation to facilitate their participation in the program. A total of 33 students: 19 girls $(58 \%)$ and 14 boys (42\%), participated in developmentally appropriate learning.

Table 1: Gender of Participants in A Celebration of Life XVI: Healthy Bodies on Earth and in Space!

\begin{tabular}{|l|l|l|l|}
\hline Program & $\begin{array}{l}\text { Total } \\
\text { Participants }\end{array}$ & Girls & Boys \\
\hline $\begin{array}{l}\text { Healthy Bodies } \\
2011 \\
\text { Elementary }\end{array}$ & 14 & 7 & 7 \\
\hline $\begin{array}{l}\text { Healthy Bodies } \\
\text { 201 } \\
\text { Middle School }\end{array}$ & 19 & 12 & 7 \\
\hline Total & $\mathbf{3 3}$ & & $\mathbf{1 4}$ \\
\hline
\end{tabular}

All specific topics for both sessions of the summer 2011 Healthy Bodies! program were related to NASA's goal of keeping astronauts healthy, and many of the educational activities used were designed by NASA to include the following content:

-a healthy diet and eating good foods

-keeping your heart and lungs healthy

-bones and the prevention of bone loss

-the nervous system and reaction time

- current NASA projects related to staying healthy in space

-historic and contemporary African American science, technology, engineering and math

(STEM) professionals, including those affiliated with NASA

Each session also included a field trip and concluded with student presentations of selected activities to peers, family members and other adult guests on the last day of each session.

Students also shared their posters of African American STEM Professionals. The program was covered by The Wisconsin State Journal (Pamela Cotant, August 1, 2011), and The Madison Times (David Dahmer, July 6, 2011).

\section{Results}

Pretests and post-tests are administered as part of each program as one indicator of students' learning. Overall, both elementary and middle school students showed an increased knowledge about health and African American STEM professionals. For example, on the pretest only 2/10 of the elementary students tested could name a single African American Scientist, Engineer or Mathematician, and answer "What do they do?" On the post-test all 11 elementary students tested could do so, and 8 of the 11 students could name 3 or more AA STEM professionals and correctly describe their contributions.

Scientific content knowledge can be measured by the pre- and post-tests, providing information regarding one aspect of program assessment. Another key indication of success is the number of 
students who had participated in previous AAEA/BTC Institute programs, or who had family members who were previous participants. Of the 14 elementary students in 2011, 2 had attended previous AAEA/BTC Institute summer sessions, 2 had family members who had previously participated in the program, and 2 were in their first year of eligibility for the program (entering 3rd grade in Fall 2011). In addition, based on the successful reputation of the program, a new group of 4 students from the Boys and Girls Club of Dane County participated in the elementary program.

In 2011, 8 of the 19 middle school students had attended previous AAEA/BTC Institute summer sessions, 3 of the new middle school students had family members who had previously participated in the programs, and 4 of the new students were referred by the Boys and Girls Club of Dane County. Of the 2011 middle school students, 6 of the 19 (32\%) had participated in the summer program at least three times. When students return for the third, fourth, fifth or sixth time, it is a strong indication of their interest in science programming. In addition, three of the young women who have participated for either five or six years, and are now headed to high school, have expressed interest in coming back next year to be assistants with the elementary program.

Table 2: Participants in A Celebration of Life XVI: Healthy Bodies on Earth and in Space!

\begin{tabular}{|l|l|l|l|l|}
\hline Program & $\begin{array}{l}\text { Total } \\
\text { Participants }\end{array}$ & $\begin{array}{l}\text { Participants } \\
\text { in Previous } \\
\text { Programs }\end{array}$ & $\begin{array}{l}\text { Have } \\
\text { Family } \\
\text { Members } \\
\text { who have } \\
\text { participated } \\
\text { previously }\end{array}$ & $\begin{array}{l}\text { First } \\
\text { Year of } \\
\text { Eligibility } \\
\text { (Grade 3) }\end{array}$ \\
\hline $\begin{array}{l}\text { Healthy Bodies } \\
\begin{array}{l}\text { 2011 } \\
\text { Elementary }\end{array}\end{array}$ & 14 & 2 & 2 & 2 \\
\hline $\begin{array}{l}\text { Healthy Bodies } \\
\text { 2011 } \\
\text { Middle School }\end{array}$ & 19 & 8 & 3 & NA \\
\hline Total & $\mathbf{3 3}$ & $\mathbf{1 0}$ & $\mathbf{5}$ & $\mathbf{2}$ \\
\hline
\end{tabular}

\section{Conclusion}

In a 2009 National Science Foundation (NSF) report, entitled Women, Minorities, and Persons with Disabilities in Science and Engineering, it was found that: "Underrepresented minorities (blacks, Hispanics, and American Indians/Alaska Natives) increased their share of S \& E [Science and Engineering] graduate students somewhat from 1996 to 2006 (from 9\% to 11\%), but their overall participation remained low. Only in psychology and the social sciences did underrepresented minorities' participation exceed 10\% in either year. Participation rates in other fields ranged from a low of 5.8\% in earth, atmospheric \& ocean sciences to a high of $9.5 \%$ in the biological sciences. These graduate study participation rates are well below the $17 \%$ share of S \& E baccalaureate degrees earned by underrepresented minorities in 2006." Supporting 
African American educational opportunities in science is essential to helping increase the number of African American students who will ultimately go into baccalaureate and graduate programs in science. (NSF, Women, Minorities, and Persons with Disabilities in Science and Engineering: 2009)

In the same report, Table 3-1 S\&E [Science and Engineering] graduate students, by field, sex, and race/ethnicity: 2008; showed that there was a total of 529,275 graduate S\&E students in the U.S. in 2008, only 28,680 (5.4\%) of whom were listed as black. (NSF, Women, Minorities, and Persons with Disabilities in Science and Engineering: 2009)

In one study examining the influence of race and gender role models on young adolescents, the author found that "the availability of race- and gender-matched role models showed a strong relationship to the developing identities of young adolescents. The availability of a race- and gender-matched role model was significantly and consistently predictive of a greater investment in achievement concerns on the part of these young adolescents." (Sabrina Zirkel, 2002). The AAEA/BTC Institute programs will continue to focus on African American STEM professional role models to help inspire students in these areas.

The exploration opportunities provided by "A Celebration of Life" enrich and enhance students' scientific knowledge and associated skills. Generating interest in science is crucial to creating a diverse work force of problem solvers, scientists, inventors and engineers for the future. It is also essential for students to see themselves in those roles. Learning about historic and contemporary African American STEM professionals ensures that they do so.

Finally, this approach is in alignment with the goals and objectives of the National Space Grant College and Fellowship Program:

- "Mission Statement \#1: Using our national network of scientists, engineers, and educators, enable the development of a diverse workforce of future scientists, engineers, technology professionals, and educators. Goal \#3: Model diversity in Space Grant leadership, programs, and activities." AAEA/BTC Institute students learned about historic and contemporary African American Science, Technology, Engineering \& Math (STEM) Professionals, featuring many who work for NASA.

- "Mission Statement \#3: Cultivate a nationwide network of partners from universities, industry, museums, science centers, state and local agencies, to pursue state and national aerospace research, education, and economic development goals. Goal \#5: Establish Space Grant as a viable state/national resource and catalyst for aerospace research, education, and economic development." The BTC Institute has continued to collaborate with AAEA to encourage interest in aerospace education and careers in an underrepresented group.

- Mission Statement \#6: Serve the general public by contributing to scientific literacy. Goal \#11: Develop Earth, Air, and Space programs to enhance public scientific literacy and to complement community needs. Goal \#12: Engage in all facets of the community in the excitement of scientific discovery using Science, Math, Engineering and Technology; (Edutainment, Process of Discovery)." (National Space Grant College and Fellowship Program Strategic Plan 2002-2006 Executive Summary) The AAEA/BTC Institute science programs were founded, in part, by the great need for quality scientific 
programming that can engage minority students and strengthen their learning in STEM content. They include sharing this information with family members and others in the community.

\section{References}

NASA Summer of Innovation, Life Science Units and Lessons for Grades 4-6, 2011. Available fromhttp://www.nasa.gov/offices/education/programs/national/summer/education_resources/lifescience_grades46/index.html

Wisconsin State Journal, School Spotlight: Summer program focuses on health, here and in space. Cotant, Pamela; August 1, 2011.

The Madison Times, Young scientists show off their nutritional knowledge. Dahmer, David; July 6, 2011.

National Science Foundation, Division of Science Resources Statistics, Women, Minorities, and Persons with Disabilities in Science and Engineering: 2009, NSF 09-305 (Arlington, VA; Jan 2009). Available from http://www.nsf.gov/statistics/wmpd

Teachers College Record Volume 104, Number 2, Is There A Place for Me? Role Models and Academic Identity among White Students and Students of Color, Sabrina Zirkel, 2002, Teachers College, Columbia University.

National Space Grant College and Fellowship Program Strategic Plan 2002-2006 Executive Summary. Available from http://www.uwgb.edu/wsgc/stratplan.aspx 